\title{
ACAROFAUNA ASSOCIATED TO PAPAYA ORCHARDS IN VERACRUZ, MEXICO
}

\author{
MARYCruZ ABATO-ZÁRATE, ${ }^{1}$ JUAN A. VILLANUEVA-JIMÉNEZ, ${ }^{2}$ GABrIEL \\ OTERO-COLINA, ${ }^{3,5}$ CATARINO ÁVILA-RESÉNDIZ, ${ }^{2}$ ELÍAS HERNÁNDEZ- \\ CASTRO,${ }^{4} \&$ NOEL REYES-PÉREZ ${ }^{1}$ \\ ${ }^{1}$ Universidad Veracruzana, Facultad de Ciencias Agrícolas, Campus Xalapa. Circuito Gonzalo \\ Aguirre Beltrán s/n Zona Universitaria C.P. 91090 Xalapa, Veracruz, MEXICO.<mabato@uv.mx>, \\ <noreyes@uv.mx> \\ ${ }^{2}$ Colegio de Postgraduados, Campus Veracruz. Km. 88.5 carretera Xalapa - Veracruz, C.P. 91690, \\ Veracruz, Ver., MEXICO.<javj@colpos.mx>, <cavire@colpos.mx> \\ ${ }^{3}$ Colegio de Postgraduados, Campus Montecillo. Km 36.5 Carr. México-Texcoco, C.P. 56230. \\ Montecillo, Texcoco, Méx. MEXICO. \\ ${ }^{4}$ Universidad Autónoma de Guerrero. Maestría en Ciencias Agropecuarias y Gestión Local de la \\ Universidad Autónoma de Guerrero. Km 2.5 Carr. Iguala-Tuxpan, Iguala, Guerrero. C.P. 40101. \\ MEXICO.<ehernandezcastro@yahoo.com.mx> \\ ${ }^{5}$ Corresponding author: <gotero@colpos.mx>
}

\begin{abstract}
Abato-Zárate, M., Villanueva-Jiménez, J. A., Otero-Colina, G., Ávila-Reséndiz, C., HernándezCastro, E. \& Reyes-Pérez, N. 2014. Acarofauna associated to papaya orchards in Veracruz, Mexico. Acta Zoológica Mexicana (n.s.), 30(3): 595-609.
\end{abstract}

ABSTRACT. Mexican agriculturists have recently noticed strong increases of mite infestations in papaya (Carica papaya L. 1753) orchards. A list of mite species associated with papaya leaves was constructed to determine the species responsible for high infestations and to identify predaceous mites as potential biological control agents. Mites were collected from three foliage strata (high, middle and low), in seven municipalities of central Veracruz State. Leaves were processed by washing and sieving. Identified species included four tetranychids: Eotetranychus lewisi (McGregor 1943), Eutetranychus banksi (McGregor 1914), Tetranychus merganser Boudreaux 1954, and Tetranychus urticae Koch 1836; as well as three phytoseiids: Euseius hibisci (Chant 1959), Galendromus helveolus (Chant 1959) and Phytoseiulus macropilis (Banks 1905), with the first two species being the most abundant. The vagrant eriophyid Calacarus citrifolii Keifer 1955 was collected in three municipalities, in the low stratum. Neither the broad mite, Polyphagotarsonemus latus (Banks 1904), nor the carmine spider mite, Tetranychus cinnabarinus (Boisduval 1867), were collected, although these species were previously recorded from this area. None of the Phytoseiid species found can be considered a recently established species; their potential as biological control agents is discussed.

Key words: Carica papaya, Phytoseiidae, Tetranychidae, Eriophyidae.

Abato-Zárate, M., Villanueva-Jiménez, J. A., Otero-Colina, G., Ávila-Reséndiz, C., Hernández-

Castro, E. y Reyes-Pérez, N. 2014. Acarofauna asociada a huertas de papayo en Veracruz, México. Acta Zoológica Mexicana (n.s.), 30(3): 595-609.

Recibido: 07/01/2014; aceptado: 06/05/2014. 
RESUMEN. Productores agrícolas en México recientemente notaron un fuerte incremento en las infestaciones de ácaros en las huertas de papayo (Carica papaya L. 1753). Se elaboró una lista de las especies de ácaros asociados con hojas de papayo para determinar las especies responsables de las altas infestaciones y para identificar a los ácaros depredadores. Los ácaros fueron colectados de tres estratos (alto, medio y bajo) en siete muncipios del centro del estado de Veracruz. Las hojas fueron procesadas por lavado y tamizado. Las especies identificadas incluyeron cuatro tetraníquidos: Eotetranychus lewisi (McGregor 1943), Eutetranychus banksi (McGregor 1914), Tetranychus merganser Boudreaux 1954 y Tetranychus urticae Koch 1836; tres fitoseidos: Euseius hibisci (Chant 1959), Galendromus helveolus (Chant 1959) y Phytoseiulus macropilis (Banks 1904), donde las dos primeras especies fueron las más abundantes. El ácaro eriófido errante Calacarus citrifolii Keifer 1955 fue colectado en tres municipios, en el estrato bajo. El ácaro blanco, Polyphagotarsonemus latus (Banks 1904), y el ácaro carmín, Tetranychus cinnabarinus (Boisduval 1867), no fueron colectados, aunque estas dos especies fueron registradas previamente en esta área. Ninguno de los fitoseidos encontrados puede ser considerado de reciente establecimiento en el área; se discute su potencial como agentes de control biológico.

Palabras clave: Carica papaya, Phytoseiidae, Tetranychidae, Eriophyidae.

\section{INTRODUCTION}

Papaya (Carica papaya L. 1753) has a diverse fauna of associated phytopahgous mites. According to Bolland et al. (1998), 30 species of the family Tetranychidae have been cited in association with this crop around the world. Oligonychus yothersi (McGregor 1914), Panonychus citri (McGregor 1916), Tetranychus desertorum Banks 1900, Tetranychus gloveri Banks 1900, Tetranychus kanzawai Kishida 1927, Tetranychus ludeni Zacher 1913, Tetranychus marianae McGregor 1950, and Tetranychus mexicanus (McGregor 1950) have been cited in Mexico on other crops (Baker \& Pritchard 1962, Estébanes-González \& Baker 1966, Tuttle et al. 1976), whereas Eotetranychus lewisi (McGregor, 1943), Eutetranychus banksi (McGregor 1914), Tetranychus cinnabarinus (Boisduval 1867), Tetranychus merganser Boudreaux 1954, and Tetranychus urticae Koch 1836, are known in Mexico as papaya pests (Rodríguez-Navarro \& Estébanes-González 1998, Rodríguez-Navarro 1999, de los Santos et al. 2000, Reséndiz \& Fausto-Moya 2010).

Phytophagous mites of other families have been collected on papaya around the world. Mesa et al. (2009) list Brevipalpus bicolpus Pritchard \& Baker 1958, Brevipalpus cromroyi Evans 1993, Brevipalpus papayensis Baker 1949, and Tenuipalpus muguanicus Ma \& Yuan 1980, from the family Tenuipalpidae. Aculops caricae Keifer 1977 (Amrine \& Stansy 1994), Calacarus brionesae Keifer 1963, Calacarus citrifolii Keifer 1955 (Jeppson et al. 1975), and Calacarus flagelliseta Flechtmann, De Moraes \& Barbosa 2001 (González et al. 2007), have been cited from the family Eriophyidae. From the family Tarsonemidae, Polyphagotarsonemus latus (Banks 1904) is known as a pest of papaya (Aubert et al. 1981). This species has been collected in Mexico and is supposed to reduce the foliar area of papaya (Alcántara et al. 2011), but the same symptoms have been attributed to papaya ringspot virus (TélizOrtiz et al. 1991). 
Among phytoseiid mites, Moraes et al. (2004) report that Euseius papayana (van der Merwe 1965), Euseius rotundus (Blommers 1973), Iphiseius martigellus El-Badry 1968, Neoseiulus teke (Pritchard \& Baker 1962) and Phytoseius purseglovei de Leon 1965 have been collected on papaya. Neoseiulus teke (Pritchard \& Baker 1962) (cited as Amblyseius bibens Blommers 1973) has been tested to determine its potential as a biological control agent of T. cinnabarinus (Lababidi \& Sengonca 1988). OteroColina (1986) mentions Lasioseius meridionalis Chant 1963, Lasioseius spp. (Ascidae), Neoseiulus anonymus (Chant \& Baker 1965) and Typhlodromus transvaalensis (Nesbitt 1951) (Phytoseiidae), as well as unidentified immature mites of the family Cheyletidae, as predaceous mites present on papaya plants in the State of Tabasco, Mexico. On the other hand, Amblyseius sp., Chelaseius sp. and Galendromus helveolus (Chant 1959) (Phytoseiidae) were collected by Valencia-Domínguez et al. (2011) on papaya in the State of Yucatan, Mexico.

Papaya growers over wide areas in Mexico have noticed a sudden increase in the importance of injuries caused by mites to this crop, a fact leading the Mexican government to consider the study of mites in this crop as a national priority (CONACyT 2006). Such an increase in the intensity of injuries could be due to the establishment of an exotic species, or alternatively an irrational use of pesticides that may have decimated populations of natural enemies, causing the sudden increase of phytophagous mites as induced pests (Huffaker et al. 1969).

Given the above facts, this study was aimed to identify the acarofauna associated with papaya crops in the State of Veracruz, where injuries caused by mites are noticeable (de los Santos et al. 2000).

\section{MATERIAL AND METHODS}

Mites were collected in orchards of the papaya cultivar Maradol (the most important cultivar in the study area) from May to October 2008, at locations indicated in Table 1. In each orchard, 20 plants were selected, evenly distributed along a diagonal transect. The crown of each plant was divided into three strata (high, middle and low) and one leaf was taken from each stratum. Each orchard was visited once, except those in El Arenal, San Marcos and Tepetates, which were visited two or three times (see Table 1).

Mites present on leaves were collected by placing batches of leaves on a column of two sieves (1000 and $32 \mu \mathrm{m}$ woven wire aperture), then washing them with a strong water stream. Mites were recovered from the finer sieve and transfered to bottles with $70 \%$ ethanol. Representative morpho-species were cleared in $85 \%$ lactic acid and then mounted on microscopic slides using Hoyer's medium (Walter \& Krantz 2009). The identification of mite species was made by the corresponding author (Gabriel Otero-Colina) using a phase contrast microscope (Carl Zeiss, Axiostar). Populations of each species and crown stratum were estimated for each collection site and date. Within a given guild (phytophagous or predatory), cases of species coexistence were 
Abato-Zárate et al.: Acarofauna of papaya in Veracruz

Table 1. Location of papaya orchards surveyed to collect and determine their associated acarofauna. Veracruz, Mexico, 2007-2008.

\begin{tabular}{|c|c|c|c|c|c|}
\hline \multirow[t]{2}{*}{ Municipality } & \multirow[t]{2}{*}{ Site } & \multirow{2}{*}{$\begin{array}{c}\text { Collection } \\
\text { date }\end{array}$} & \multicolumn{3}{|c|}{ Geographic position } \\
\hline & & & Latitude $\mathrm{N}$ & Longitude W & Altitude (m) \\
\hline Cotaxtla & Loma Angosta & 09-05-07 & $18^{\circ} 53^{\prime} 00.0^{\prime \prime}$ & $96^{\circ} 24^{\prime} 14.5^{\prime \prime}$ & 54 \\
\hline Cotaxtla & Mata Tambor & $26-12-07$ & $18^{\circ} 53^{\prime} 38.0^{\prime \prime}$ & $96^{\circ} 22^{\prime} 42.2^{\prime \prime}$ & 70 \\
\hline Cotaxtla & Cerro del Frayle & $15-03-08$ & $18^{\circ} 55^{\prime} 21.7 \prime$ & $96^{\circ} 21^{\prime} 50.9^{\prime \prime}$ & 42 \\
\hline \multirow[t]{3}{*}{ M. F. Altamirano } & Tepetates & $18-11-07$ & $19^{\circ} 11^{\prime} 38.1^{\prime \prime}$ & $96^{\circ} 20^{\prime} 17.6 ”$ & 14 \\
\hline & Tepetates & 07-01-08 & $19^{\circ} 11^{\prime} 38.1 "$ & $96^{\circ} 20^{\prime} 17.6^{\prime \prime}$ & 14 \\
\hline & Tepetates & 07-07-08 & $19^{\circ} 11 ' 38.1 "$ & $96^{\circ} 20^{\prime} 17.6^{\prime \prime}$ & 14 \\
\hline M. F. Altamirano & San Juan de Estancia & $04-12-07$ & $19^{\circ} 08^{\prime} 18.8^{\prime \prime}$ & $96^{\circ} 20^{\prime} 07.6^{\prime \prime}$ & 3 \\
\hline Paso de Ovejas & Arenal, San Marcos & $\begin{array}{l}24-08-07 \\
11-01-08\end{array}$ & $19^{\circ} 18^{\prime} 05.3 ”$ & $96^{\circ} 23 ’ 53.3^{\prime \prime}$ & 28 \\
\hline Puente Nacional & Paso de Varas & $11-01-08$ & $19^{\circ} 21^{\prime} 23.3^{\prime \prime}$ & $96^{\circ} 25^{\prime} 05.3^{\prime \prime}$ & 46 \\
\hline Puente Nacional & Parcela Escolar & 07-02-08 & $19^{\circ} 19^{\prime} 52.4^{\prime \prime}$ & $96^{\circ} 28^{\prime} 47.4^{\prime \prime}$ & 99 \\
\hline Actopan & Mozomboa & $18-11-07$ & $19^{\circ} 30 ’ 37.6 "$ & $96^{\circ} 27^{\prime} 55.7^{\prime \prime}$ & 63 \\
\hline Alto Lucero & Santa Anal & $25-05-07$ & $19^{\circ} 53^{\prime} 25.1^{\prime \prime}$ & $96^{\circ} 30^{\prime} 42.3 \prime$ & 9 \\
\hline Alto Lucero & Santa Ana 2 & $25-05-07$ & $19^{\circ} 53^{\prime} 06.4^{\prime \prime}$ & $96^{\circ} 30^{\prime} 50.7^{\prime \prime}$ & 15 \\
\hline Emiliano Zapata & La Cumbre & $02-05-07$ & $19^{\circ} 23$ ' 18.7’" & $96^{\circ} 38^{\prime} 45.6^{\prime \prime}$ & 353 \\
\hline
\end{tabular}

recorded to determine possible associations or exclusion. Faunistic data were compared with previous records.

\section{RESULTS}

Three mite species of the family Tetranychidae, one of the family Eriophyidae (both phytophagous) and three of the family Phytoseiidae (tentatively predaceous) were collected. The mean number of specimens from each site and stratum appear in Table 2. Tetranychus cinnabarinus and P. latus, cited by de los Santos et al. (2000) as among the most important phytosanitary problems in the State of Veracruz, were never found.

The most widely disseminated phytophagous mite species was $E$. banksi, found in all sites except Santa Ana 2. It was followed by E. lewisi, found in all sites except Santa Ana 1 and 2. This second species reached the highest population levels, up to 66 specimens per leaf. The remaining phytophagous mites were collected in few places each (Table 2).

The phytoseiids Euseius hibisci (Chant 1959) and G. helveolus were widespread, the first one with higher populations. In Cerro del Frayle and Santa Ana, E. hibisci attained 21 specimens per leaf in the middle and low strata. A single specimen of 
Table 2. Mean number of mite specimens per leaf collected from 20 pooled papaya leaves in 13 sites in central Veracruz State, Mexico, 2008.

\begin{tabular}{|c|c|c|c|c|c|c|c|c|}
\hline Site & Strata & $E . b^{\mathrm{a}}$ & E. $l^{\mathrm{b}}$ & T. $u^{\mathrm{c}}$ & T. $m^{\mathrm{d}}$ & $G . h^{\mathrm{e}}$ & $E . h^{\mathrm{f}}{ }^{\mathrm{f}}$ & C. c. $^{\mathrm{g}}$ \\
\hline \multirow{3}{*}{$\begin{array}{l}\text { Loma } \\
\text { Angosta }\end{array}$} & High & 21.4 & 45.0 & 0.0 & 0.0 & 0.1 & 1.1 & 0.0 \\
\hline & Medium & 15.4 & 57.6 & 0.0 & 2.9 & 0.0 & 0.1 & 0.2 \\
\hline & Low & 22.1 & 52.5 & 0.0 & 22.5 & 2.4 & 5.0 & 0.2 \\
\hline \multirow{3}{*}{$\begin{array}{l}\text { Mata } \\
\text { Tambor }\end{array}$} & High & 4.7 & 7.85 & 0.0 & 0.0 & 0.2 & 0.3 & 0.0 \\
\hline & Medium & 10.7 & 15.0 & 0.0 & 0.0 & 1.8 & 0.8 & 0.0 \\
\hline & Low & 22.2 & 12.9 & 0.0 & 0.0 & 2.9 & 3.1 & 0.0 \\
\hline \multirow{3}{*}{$\begin{array}{l}\text { Cerro del } \\
\text { Frayle }\end{array}$} & High & 7.8 & 34.7 & 0.0 & 0.0 & 0.0 & 8.3 & 0.0 \\
\hline & Medium & 4.5 & 16.9 & 0.0 & 0.0 & 0.2 & 22.0 & 0.1 \\
\hline & Low & 0.3 & 13.6 & 0.0 & 0.0 & 0.1 & 13.3 & 0.0 \\
\hline \multirow{3}{*}{$\begin{array}{l}\text { Tepetates } \\
18 / 11 / 07\end{array}$} & High & 0.0 & 5.2 & 0.0 & 0.0 & 0.0 & 1.2 & 0.0 \\
\hline & Medium & 0.0 & 5.5 & 0.0 & 0.0 & 0.0 & 0.9 & 0.0 \\
\hline & Low & 10.0 & 20.6 & 0.0 & 0.0 & 0.3 & 1.8 & 0.0 \\
\hline \multirow{3}{*}{$\begin{array}{l}\text { Tepetates } \\
\text { 07/01/08 }\end{array}$} & High & 0.2 & 16.0 & 0.0 & 0.0 & 0.6 & 0.0 & 0.0 \\
\hline & Medium & 0.2 & 16.0 & 0.0 & 0.0 & 0.5 & 3.0 & 0.0 \\
\hline & Low & 4.0 & 36.0 & 0.0 & 0.0 & 3.0 & 0.0 & 0.0 \\
\hline \multirow{3}{*}{$\begin{array}{l}\text { Tepetates } \\
07 / 07 / 08\end{array}$} & High & 0.1 & 3.0 & 0.0 & 0.0 & 0.1 & 0.1 & 0.0 \\
\hline & Medium & 2.0 & 21.0 & 0.0 & 0.0 & 0.3 & 0.0 & 0.0 \\
\hline & Low & 0.6 & 36.0 & 0.0 & 0.0 & 1.0 & 0.3 & 0.0 \\
\hline \multirow{3}{*}{$\begin{array}{l}\text { S.J. de } \\
\text { Estancia }\end{array}$} & High & 0.3 & 4.9 & 0.0 & 0.0 & 0.0 & 0.1 & 0.0 \\
\hline & Medium & 4.5 & 8.5 & 0.0 & 0.9 & 0.0 & 0.1 & 0.0 \\
\hline & Low & 7.8 & 6.5 & 0.0 & 4.7 & 0.0 & 0.1 & 0.0 \\
\hline \multirow{3}{*}{$\begin{array}{l}\text { El Arenal } \\
\text { Date } 1\end{array}$} & High & 0.5 & 0.7 & 0.0 & 0.0 & 0.7 & 0.7 & 0.0 \\
\hline & Medium & 0.2 & 0.2 & 0.0 & 0.0 & 0.3 & 0.4 & 0.0 \\
\hline & Low & 1.7 & 0.1 & 0.0 & 0.0 & 0.2 & 0.3 & 3.4 \\
\hline \multirow{3}{*}{$\begin{array}{l}\text { El Arenal } \\
\text { Date } 2\end{array}$} & High & 0.6 & 1.9 & 0.0 & 0.0 & 0.0 & 0.4 & 0.0 \\
\hline & Medium & 0.9 & 3.0 & 0.0 & 0.0 & 0.1 & 0.9 & 0.0 \\
\hline & Low & 2.0 & 9.3 & 0.0 & 0.0 & 0.1 & 0.1 & 0.0 \\
\hline \multirow{3}{*}{$\begin{array}{l}\text { Paso de } \\
\text { Varas }\end{array}$} & High & 0.0 & 0.2 & 0.0 & 0.0 & 0.0 & 0.3 & 0.0 \\
\hline & Medium & 0.5 & 1.4 & 0.0 & 0.0 & 0.1 & 1.0 & 0.0 \\
\hline & Low & 2.5 & 2.5 & 0.0 & 0.0 & 0.0 & 3.5 & 0.0 \\
\hline \multirow{3}{*}{$\begin{array}{l}\text { Parcela } \\
\text { Escolar }\end{array}$} & High & 0.0 & 1.0 & 0.0 & 0.0 & 0.0 & 0.1 & 0.0 \\
\hline & Medium & 1.3 & 3.3 & 0.0 & 0.0 & 0.0 & 0.1 & 0.0 \\
\hline & Low & 5.9 & 11.5 & 0.0 & 0.0 & 0.2 & 1.4 & 0.0 \\
\hline
\end{tabular}


Table 2. Continues.

\begin{tabular}{llccccccc}
\hline \multicolumn{1}{c}{ Site } & Strata & $E . b .^{\mathrm{a}}$ & $E . l .^{\mathrm{b}}$ & $T . u{ }^{\mathrm{c}}$ & $T . m .^{\mathrm{d}}$ & $G . h^{\mathrm{e}}$ & $E . h^{\mathrm{f}}$ & $C . c .^{\mathrm{g}}$ \\
\hline Mozomboa & High & 1.6 & 5.8 & 0.0 & 0.0 & 0.0 & 0.4 & 0.0 \\
& Medium & 6.2 & 19.7 & 0.0 & 0.0 & 0.2 & 0.3 & 0.0 \\
& Low & 25.6 & 66.6 & 0.0 & 0.0 & 1.8 & 1.0 & 0.0 \\
\multirow{3}{*}{ Santa Ana } & High & 0.4 & 0.0 & 2.3 & 8.7 & 0.0 & 1.7 & 0.0 \\
& Medium & 0.0 & 0.0 & 0.2 & 0.9 & 0.3 & 16.5 & 0.0 \\
& Low & 0.2 & 0.0 & 1.3 & 5.1 & 0.3 & 21.7 & 0.0 \\
\multirow{3}{*}{ Santa Ana } & High & 0.0 & 0.0 & 4.4 & 16.4 & 0.0 & 9.6 & 0.0 \\
& Medium & 0.0 & 0.0 & 14.1 & 52.9 & 0.0 & 0.5 & 0.0 \\
& Low & 0.0 & 0.0 & 18.4 & 69.1 & 0.1 & 6.9 & 0.0 \\
& High & 0.1 & 0.3 & 0.0 & 0.0 & 0.2 & 1.5 & 0.0 \\
& Medium & 0.0 & 0.3 & 0.0 & 0.0 & 0.2 & 1.5 & 0.0 \\
& La & 0.0 & 0.3 & 0.0 & 0.0 & 0.0 & 3.7 & 0.0
\end{tabular}

${ }^{\mathrm{a}}$ Eutetranychus banksi, ${ }^{\mathrm{b}}$ Eotetranychus lewisi, ${ }^{\mathrm{c}}$ Tetranychus urticae, ${ }^{\mathrm{d}}$ T. merganser, ${ }^{\mathrm{e}}$ Galendromus helveolus, ${ }^{\mathrm{f}}$ Euseius hibisci, ${ }^{\mathrm{g}}$ Calacarus citrifolii. ${ }^{\mathrm{a}-\mathrm{d}}$ Tetranychidae, ${ }^{\mathrm{e}-\mathrm{f}}$ Phytoseiidae, ${ }^{\mathrm{h}}$ a single specimen of Phytoseiulus macropilis (Phytoseiidae) was collected in the middle stratum.

Phytoseiulus macropilis (Banks 1905) was found in Tepetates. As a general trend, mites congregated mainly in the middle and low strata, although there was variation among species. Figure 1 presents the mean number of specimens for each species per stratum.

\section{DISCUSSION}

\section{Notes on the phytophagous mites}

Eotetranychus lewisi. This mite species is polyphagous and is locally known as "araña cristalina" (crystalline mite) or "ácaro blanco" (white mite). Bolland et al. (1998) present a list of 64 plant hosts for this mite. It has a wide distribution in the Americas, mainly in tropical and subtropical areas. It is known also from countries such as Libya, the Madeira Islands, South Africa, Philippines and Taiwan, where it has been dispersed most likely by trading contaminated poinsettia Euphorbia pulcherrima Willd. ex Klotzsch 1834 (Corpus-Raros 2001, Ho \& Shih 2004). It has been found on papaya trees in Mexico, Costa Rica, El Salvador, Honduras and Nicaragua (Salas 1978, EPPO 2006).

Colonies produce profuse webbing (Jeppson et al. 1975) along the primary and secondary abaxial veins, eventually covering the lower side of the leaf (Reséndiz \& 


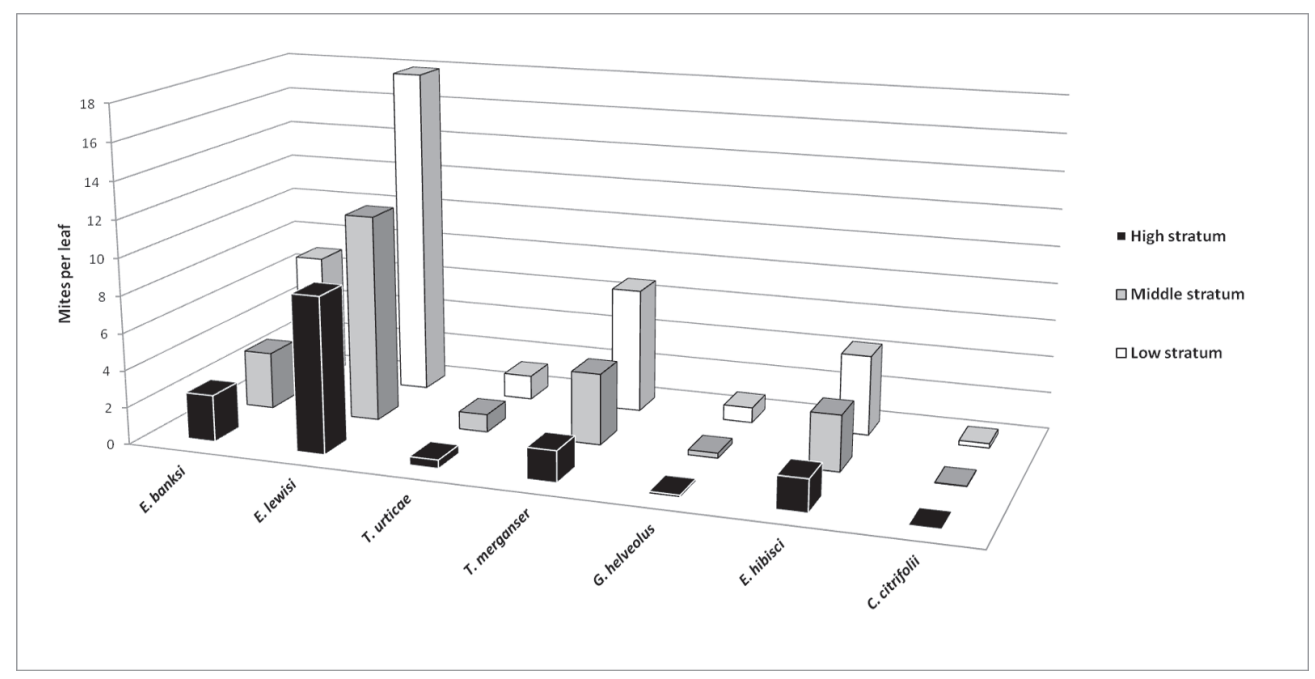

Figure 1. Mean number of mites of each species per stratum. Veracruz, Mexico, 2008.

Fausto-Moya 2010, corroborated by the authors). Of all species found during our surveys, E. lewisi attained the highest population levels in the middle (mature leaves) and high strata (younger leaves) (Fig. 1). Besides two exceptions (Loma Angosta and San Juan de la Estancia, see Table 2), in the sites where E. lewisi was present, neither $T$. merganser nor $T$. urticae were found, suggesting a competitive displacement among those species. Ochoa et al. (1991) indicate that E. lewisi causes severe malformations and reductions of leaf area to the extent that only the veins remain. Similar malformations have been attributed to another mite, P. latus (Aubert et al. 1981, Acuña \& Agostini 2004), and also to papaya ring spot virus (PRSV-p) (TélizOrtiz et al. 1991). This mite species and the PRSV-p were present in the study area (GIP 1995), making it almost impossible to link a specific symptom to each source in the field, except for the aqueous marking on the stem by the virus, and the presence of the webbing left by mites.

Eutetranychus banksi. This species is known as "araña texana de los cítricos" (Texas citrus mite), and was first described in Orlando, Florida, USA (McGregor 1914). It also was described with different names in the USA, Mexico, Argentina, Peru, Italy, Israel, Egypt, South Africa and India, but Pritchard \& Baker (1955) placed those names under the synonymy of $E$. banksi, and postulated that trading of citrus and ornamental plants disseminated the mite throughout the world. However, Bolland et al. (1998) indicated that most of the distribution data for this species might be related to Eutetranychus orientalis (Klein 1936), a species often confused with $E$. banksi. The last species is distributed in the Americas on 84 host plant species. 
In contrast with other mite species, this mite prefers to settle on the adaxial (upper) surface of leaves where it produces little webbing. It has been collected simultaneously with other tetranychid mites, which tend to thrive on the abaxial surface. It causes yellowing, leaf drop, reduction of vigor and yield, and is considered a very harmful fruit tree pest in Mexico (Landeros et al. 2004). Leaf drop reduces photosynthetic activity in papaya and fruits are exposed to sunlight when leaves of middle to low strata fall, resulting in fruit-burn and a subsequent reduction in quality (de los Santos et al. 2000). Overall, populations were rather low, with only the population found in Loma Angosta considered to be above an economic or operational threshold of concern, with a mean of 52 mites per leaf.

Tetranychus merganser. This species was originally described in privet (Ligustrum vulgare L. 1753) in Baton Rouge, Louisiana, USA (Boudreaux 1954). It has been poorly studied and was not considered an important pest; however, it has expanded recently its distribution and host range, becoming an important invasive pest. This mite was collected on Thalictrum sp. in China (Wang \& Ma 1993) and recently has been detected in Japan on pumpkin imported from Mexico and the USA (Ullah et al. 2011). Based on demografic parameters, Ullah et al. (2011) demonstrated that this mite succesfully thrives under temperatures ranging from 15 to $35^{\circ} \mathrm{C}$, showing a preference for warm weather.

In Mexico, T. merganser has been cited on C. papaya, Solanum nigrum L. 1753, Solanum rostratum Dunal 1813 (Tuttle et al. 1976), Arachis hypogaea L. 1753, Capsicum frutescens L. 1753, Tagetes erecta L. 1753, Ficus sp., Hydrangea macrophylla (Thunb. 1784) and Xanthosoma robustum Schott 1853 (Rodríguez-Navarro \& Estébanes-González 1998, Rodríguez-Navarro 1999), while Lomelí-Flores et al. (2008) recorded it attacking pricky pear (Opuntia ficus-indica [L. 1753]), a new record for this host.

On the other hand, Valencia-Domínguez et al. (2011) qualify T. merganser as the most harmful mite of papaya in the State of Yucatan. In recent years in Mexico, papaya (Abato-Zárate et al. 2011, FAO 2012) and prickly pear (Flores et al. 1995) have changed from subsistence crops to high income exportation products, intensively cultivated and submitted to frequent applications of pesticides. We suggest that $T$. merganser has become an important pest as a result of cultural changes with excesive use of pesticides, reproducing the outbreaks of mites as induced pests described by Huffaker et al. (1969).

Tetranychus urticae. This species is polyphagous, recorded from 933 hosts wordwide (Bolland et al. 1998). In Mexico it has been found on Acacia greggii (A. Gray 1852), C. papaya, Chrysantemum indicum L. 1753, Citrus x limon (L. 1768), Cucumis sativus L. 1753, Cynara scolymus L. 1753, Dhalia sp., Fragaria mexicana Schltdl. 1839, Gossypium hirsutum L. 1763, Helianthus annuus L. 1753, Impatiens sultanii Hook 1882, Manihot esculenta Crantz 1766, Nicotiana tabacum L. 1753, Phaseolus 
vulgaris L. 1753, Physalis ixocarpa Brot. 1819, Polianthes tuberosa L. 1753, Rhododendron indicum (L.) Sweet 1832, Rosa sp., Solanum melongena L. 1753, Thevetia peruviana (Pers.) Schum. 1895, Ulmus sp., Vitis vinifera L. 1753, and Zea mays L. 1753 (compiled from: Tuttle et al. 1976, García 1981, Otero-Colina 1986, EstébanesGonzález \& Rodríguez-Navarro 1991, Rodríguez-Navarro \& Estébanes-González 1998). Mite colonies settle mainly on the abaxial surface of leaves, and injury appears as yellow spots and profuse webbing.

Given the wide host range of T. urticae, including papaya in Mexico (García 1981, Rodríguez-Navarro 1999), it is surprising that it was collected only in two orchards during the present study, where it showed low population levels (Table 2, Fig. 1). Reséndiz \& Fausto-Moya (2010) identified both T. urticae and T. cinnabarinus on papaya in Colima State, Mexico, discriminating them by their color and the shape of microtubercles. A discussion persists whether T. cinnabarinus and T. urticae form a single species or can be separated in two different species (Zhang \& Jacobson 2000). During our surveys we did not find specimens similar to T. cinnabarinus, suggesting that the specimens cited in Veracruz as T. cinnabarinus by de los Santos et al. (2000) could have been misidentified, and actually corresponded to T. merganser, whose females are also red.

Calacarus citrifolii. This species was originally collected in South Africa (Keifer 1955). It is special among eriophyids because it has a wide host range (attacking Brunfelsia sp., C. papaya, Dianthus sp., E. pulcherrima, Lippia sp., Mimusops sp., Pappea sp., Passiflora quadrangularis L. 1759, Prunus persica (L.) Batsch. 1801, Rhamnus sp., Rhus sp. and Zanthedeschia aethiopica [L.] Spreng. 1826), plants belonging to 11 families (Oldfield 1996, Smith-Meyer 1996). In South Africa it is associated with (or transmits) "concentric ring blotch" citrus disease (Kotzé et al. 1987). Pantoja et al. (2002) found this mite in the East Antilles, as did de la Torre (2005) in Cuba; in both cases they were collected on papaya trees. These authors did not observe injuries in papaya associated with the infestation of this mite, similar to the present surveys. Besides not been detected in Mexico yet, the disease has a greater potential risk by having its vector in place; in addition, several types of citrus that serve as potential hosts are present in the area. Our data is the first finding of $C$. citrifolii in the study area. Given its wide host range, it is difficult to postulate how it has moved from Africa to the Antilles and then to Mexico, and it can only be suggested that it moved with contaminated material, such as citrus or poinsettias.

Calacarus citrifolii might be a species recently established in papaya agroecosystems in Veracruz. Since it was already cited in the State of Yucatan by ValenciaDomínguez et al. (2011), we suggest it is widespread in Mexico, although it has been overlooked because it does not cause obvious injuries. Thus, it is postulated that this species is not associated with the sudden increase of mite populations and their damage, which has been noticed by growers in Mexico in recent years. 


\section{The complex of phytophagous mites on papaya}

The phytophagous mites living on papaya trees included: C. citrifolii, E. lewisi, E. banksi, T. merganser and T. urticae. They constitute a complex; more than one species can be present in a single plant or orchard (Table 2). Eutetranychus banksi and C. citrifolii were able to coexist with all other species, but in most cases E. lewisi, $T$. merganser and T. urticae were not found together, suggesting mutual exclusion. The coexistence of $E$. banksi with other tetranychids can be explained because this species inhabits the adaxial surface of leaves, reducing competition with the abaxial-living tetranychids. In contrast, E. lewisi, T. merganser and T. urticae live on the abaxial surface and the three produce abundant webbing, preventing individuals of different species from settling (Gerson 1985). Similarly, Karban \& English-Loeb (1990) demonstrated that colonies of Eotetranychus willamettei (McGregor 1917) established on grape interfere with the settling of Tetranychus pacificus McGregor 1919, phenomenon termed "vaccination" by the authors.

Polyphagotarsonemus latus was never found infesting papaya in our surveys in the central region of Veracruz. Valencia-Domínguez et al. (2011) also did not find this mite in the State of Yucatan. This species has been reported in Mexico to attack several crops, mostly pepper (Capsicum annuum L. 1753) (Alcántara et al. 2011). Experimentally, these authors inoculated this mite onto papaya, where it caused reductions in leaf area; however, they also noticed that colonies of $P$. latus persisted on the plant for a short period of time, abandoning the plant or dying later; it might explain why we did not find this species during the surveys, even though we have been able to find P. latus on pepper in this area (additional observations of the authors). Leaf malformations and leaf area reductions were found during the study. The frequent presence of $E$. lewisi on young leaves suggests that such malformations could be caused by this species, not by P. latus; although PRSV-p, another suspected etiological agent, was also present in the study area (Téliz-Ortiz et al. 1991).

Papaya is commercially exploited in a productive cycle that lasts about 1.5 years before being cut down, resulting in death of the infesting mites. In a new orchard, acarofauna must start de novo from mites present on neighboring plants, whether in the nursery or in the field. Any of the above species are able to establish on papaya leaves, but the first one settling down prevents colonization by the others, especially in the case of E. lewisi, T. merganser and T. urticae.

Calacarus citrifolii is the only species recently established in Mexico and it does not cause obvious injuries (Valencia-Domínguez et al. 2011, our observations). All remaining phytophagous mites were already present in Mexico, however these findings clarifies much of the literature already in use about the identity of papaya mites in Veracruz, Mexico. Individually or combined, mites can reach high population levels on papaya leaves. On this basis, recent papaya mite outbreaks in Mexico cannot be associated with a single species, but to tetranychids as a complex; additional species 
could be added to the list. Appropriate identification might help to apply the most appropriate pest management strategies.

\section{Notes on the predaceous mites collected}

Three species of the family Phytoseiidae were found, G. helveolus, E. hibisci and $P$. macropilis. These predatory mites are widely distributed in the Americas, including the Antilles, but E. hibisci has been found in Angola, India and Madeira Island (Moraes et al. 2004), and P. macropilis is present in many sites around the world, as a result of its massive propagation and use as a biological control agent (Ferla et al. 2011). The distribution of all three species includes localities North and South of the study area, so they are considered part of the native fauna or at least have been present there for a long time. There are no data on the introductions of any of these species into the study area for biological control purposes, so it is postulated that they could have immigrated and established by themselves on papaya.

Galendromus helveolus and E. hibisci were found in almost all collection sites where they probably fed on phytophagous mites. In 25 out of 45 samples, both species were present (Table 2), suggesting that there is no interference between them. In contrast, only one specimen of $P$. macropilis was found in Tepetates.

The species composition of phytoseiid mites collected in Veracruz contrasts with the species composition identified by Otero-Colina (1986) on papaya in the neighboring State of Tabasco in a more humid environment, with not a single species present in both environments. Although in both cases the phytoseiids found were widespread in the Americas (Moraes et al. 2004), the fauna found by Otero-Colina included members of the families Ascidae and Cheyletidae, more common in tropical and subtropical crops (Christian \& Karg 2006, Laing \& Knop 1982). Data from Otero-Colina were taken before papaya changed from a subsistence crop with local marketing to an export commodity receiving frequent pesticide applications. Thus, the fauna found in the present study characterized this highly altered agroecosystems, with a fauna composed of non-native predators, opposite to what was reported for Tabasco.

Following the characterization of phytoseiid life-styles developed by McMurtry \& Croft (1997), G. helveolus is placed in type II, predators selective for tetranychids producing profuse webbing. Euseius hibisci belongs to type IV, pollen feeders and generalist predators. Type I and II predatory mites are morphologically and physiologically adapted to prey on mite species forming dense colonies and producing abundant webbing; they are voraceous and highly fecund when feeding on mites. That is why they are favored for use as biological control agents. For example, $G$. helveolus has been tested as a biocontrol agent for Oligonychus perseae Tuttle, Baker \& Abbatiello 1976 (Takano-Lee \& Hoodle 2002), Oligonychus punicae (Hirst 1926) (Tanigoshi \& McMurtry 1977), Eotetranychus sexmaculatus (Riley 1890) (Muma 
1970), E. banksi, Brevipalpus californicus (Banks 1904) (Chen et al. 2006), P. citri and Phyllocoptruta oleivora (Ashmead 1879) (Cáceres \& Childers 1991).

Type IV phytoseiid mites feed mainly on pollen, but they are facultative predators. They could play a role in the natural regulation of phytophagous mites, but they are not capable of controlling tetranychid mite outbreaks, discouraging their massive propagation and use for augmentative control. However, E. hibisci has shown potential to control P. citri (McMurtry 1985), and even T. urticae, which produces abundant webbing (Hernández-Ortiz et al. 1994).

The collection method used did not allow us to observe the activity of predaceous mites. However, life styles described by McMurtry \& Croft (1997) lead us to suggest that $E$. hibisci preys on $E$. banksi, which produces little webbing, while $G$. helveolus preys on E. lewisi, T. merganser and T. urticae, producers of abundant webbing. A combination of both predators could increase efficiency in the natural control of the papaya pest mite complex. Euseius hibisci is an indicator of less disturbed agroecosystems, whereas $G$. helveolus indicates perturbed agroecosystems (McMurtry \& Croft 1997). Thus, we consider that papaya agroecosystems in Veracruz are in an intermediate state of perturbation.

ACKNOWLEDGEMENTS. This research was supported by the Consejo Nacional de Ciencia y Tecnología, Mexico; project CB-2008-01, 000000000106183. We thank Bruce Campbell and Eliseo García Pérez for their helpful review of the manuscript.

\section{LITERATURE CITED}

Abato-Zárate, M., Villanueva-Jiménez, J. A., Reta-Mendiola, J., Avila-Reséndiz, C., Otero-Colina, G. \& Hernández-Castro, E. 2011. Simultaneous productive growth groups (SPGG): innovation on papaya mite management. Tropical and Subtropical Agroecosystems, 13: 397-407.

Acuña, L. E. \& Agostini, J. P. 2004. Búsqueda del agente causal de los síntomas del mosaico del mamón Carica papaya L. Citrusmisiones, 29:17-20.

Alcántara, J. J. A., Santillán-Galicia, M. T., Otero-Colina, G., Mora A., A., Gutiérrez E., M. A. \& Hernández C., E. 2011. Relación entre Polyphagotarsonemus latus (Acari: Tarsonemidae) y el virus de la mancha anular del papayo (PRSV-p). Revista Colombiana de Entomología, 37: 228-233.

Amrine, J. W. \& Stansy, T. A. 1994. Catalogue of the Eriophyoidea (Acari: Prostigmata) of the World. Indira Publishing House, West Bloomfield, USA, 1186 pp.

Baker, E.W. \& Pritchard, A. E. 1962. Arañas rojas de América Central. Revista de la Sociedad Mexicana de Historia Natural, 23: 309-340.

Bolland, H. R., Gutierrez, J. \& Flechtmann, C. H. W. 1998. World catalogue of the spider mite family (Acari: Tetranychidae). Leiden, Boston Köln, Brill, 392 pp.

Boudreaux, H. B. 1954. New species of tetranychid mites. Pan-Pacific Entomologist, 30: 181-183.

Cáceres, S. \& Childers, C. C. 1991. Biology and life tables of Galendromus helveolus (Acari: Phytoseiidae) on Florida citrus. Environmental Entomology, 20: 224-229.

Chen, T. Y., French, J. V., Liu, T. X. \& Da Graca, J. V. 2006. Predation of Galendromus helveolus (Acari: Phytoseiidae) on Brevipalpus californicus (Acari: Tenuipalpidae). Biocontrol Science and Technology, 16: 753-759. 
Christian, A. \& Karg, W. 2006. The predatory mite genus Lasioseius Berlese, 1916. Abhandlungen und Berichte des Naturkundemuseums, Forschungsstelle, Görlitz, 77: 99-250.

CONACyT (Consejo Nacional de Ciencia y Tecnología) (2006) Términos de referencia Convocatoria de Investigación Científica Básica 2008. Available from: http://www.conacyt.gob.mx/fondos/FondosSectoriales/SEP/Convocatoria\%20200801/Terminos-de-referencia-CB-2008.pdf. (Accessed 20 March 2013).

Corpus-Raros, L. A. 2001. New mite pests and new host records of phytophagous mites (Acari) from the Philippines. Philippine Agricultural Science, 84: 341-351.

de la Torre, P. E. 2005. Colectas acarológicas de ciudad de la Habana registradas por la sanidad vegetal. Fitosanidad, 9: 3-8.

de los Santos, R. F., Becerra L., E. N., Mosqueda, V., Vásquez, H. A. \& Vargas, G. A. B. 2000. Manual de producción de papaya en el estado de Veracruz. INIFAP-SAGAR-Fundación Produce Veracruz. Centro de Investigaciones Agrícolas del Golfo Centro. Campo Experimental Cotaxtla. Folleto Técnico Núm. 17. México, 87 pp.

Estébanes-Gonzalez, M. L. \& Baker, E. W. 1966. Las arañas rojas de México (Acarina: Tetranychidae). Anales de la Escuela Nacional de Ciencias Biológicas, México, 15: 61-133.

Estébanes-González, M. L. \& Rodríguez-Navarro, S. 1991. Observaciones sobre algunos ácaros de las familias Tetranychidae, Eriophyidae, Acaridae y Tarsonemidae (Acari), en hortalizas de México. Folia Entomológica Mexicana, 83: 199-212.

EPPO (European and Mediterranean Plant Protection Organization) (2006) Eotetranychus lewisi. Bulletin OEPP/EPPO. 36: 161-163. Available from: http://onlinelibrary.wiley.com/doi/10.1111/j.13652338.2006.00929.x/pdf (Accessed 07 April 2013).

FAO. 2012. FAOSTAT. Available from: http://faostat3.fao.org/home/index.html (Accessed 20 March 2013).

Ferla, N. J., Marchetti, M., Johann, L. \& Haetinger, C. 2011. Functional response of Phytoseiulus macropilis under different Tetranychus urticae (Acari: Phytoseiidae, Tetranychidae) population density in laboratory. Zoologia, 28: 17-22.

Flores, V. C. A., Luna, E. J. M.\& Ramírez, M. P. 1995. Mercado mundial del nopalito. ASERCAUACH-CIESTAAM Chapingo, México. $115+53$ pp.

García, M. C. 1981. Lista de insectos y ácaros perjudiciales a los cultivos en México. Fitófilo, 86: 1196.

Gerson, U. 1985. Webbing, pp. 223-232. In: W. Helle and M. W. Sabelis (Eds.) Spider mites, their biology, natural enemies and control. World Crop Pests Series Vol. 1A. Elsevier, Wageningen.

GIP (Grupo Interdisciplinario del Papayo): Flores-Revilla, C.; García, E., Nieto-Ángel, D., Téliz-Ortiz, D. \& Villanueva-Jiménez, J. A. 1995. Integrated management of papaya in Mexico. Acta Horticulturae, 370: 151-158.

González, G. N., Rodríguez, M. A., de la Torre S., P. E., Lastres, G. N., García, M. X. \& Ramos, G. N. 2007. Primera cita del ácaro Calacarus flagellista Flechtmann, de Moraes y Barbosa 2001 sobre el cultivo de papaya "Maradol Roja" en Cuba. Boletín de Sanidad Vegetal Plagas, 33: 45-51.

Hernández-Ortiz, E., Otero-Colina, G., Badii, M. H., López-Collado, J. \& Flores, A. E. 1994. Ciclo y tablas de vida de Euseius hibisci alimentado con Tetranychus urticae (Acari: Phytoseiidae, Tetranychidae) y con polen. Agrociencia serie Protección Vegetal, 5: 7-23.

Ho, C. C. \& Shih, S. P. 2004. Eotetranychus lewisi, a new pest of poinsettia from Taiwan. Plant Protection Bulletin (Taipei), 46: 173-176.

Huffaker, C. B., van de Vrie, M. \& McMurtry, J. A. 1969. The ecology of tetranychid mites and their natural control. Annual Review of Entomology, 14: 125-74. 
Jeppson, L. R., Keifer, H. H. \& Baker, E. W. 1975. Mites injurious to economic plants. Berkeley, Los Angeles, London, University of California Press. U. S. A. 614 pp.

Karban, R. \& English-Loeb, G. M. 1990. A "vaccination" of Willamette spider mites (Acari: Tetranychidae) to prevent large populations of Pacific spider mites on grapevines. Journal of Economic Entomology, 83: 2252-2257.

Keifer, H. H. 1955. Eriophyid studies XXIII. California Department of Agriculture Bulletin, 44: 126130.

Kotzé, J. M., Putterill, J. F., Labuschagne, N. \& Wehner, F. C. 1987. Occurrence of a spiroplasmalike organism in lesions of concentric ring blotch on citrus. Phytophylactica, 19: 363-364.

Lababidi, M. S. \& Sengonca, Ç. 1988. Die Wirksamkeit der verschiedenen Raubmilbenarten gegenüber der Baumwollspinnmilbe, Tetranychus cinnabarinus Boisd. (Acari: Tetranychidae). Mitteilungen der Deutschen Gesellschaft für Allgemeine und Angewandte Entomologie, 6: 272-277.

Laing, J. E. \& Knop, N. F. 1982. Potential use of predaceous mites other than Phytoseiidae for biological control of orchard pests, pp. 28-35. In: M.A. Hoy, G. L. Cunningham and L. Knutson (Eds.) Biological control of pests by mites. Proceedings. April 5-7, 1982. University of California, Berkeley CA. Special publication / Division of Agriculture and Natural Resources, University of California, USA.

Landeros, L., Cerna, E., Badii, M. H., Varela, S. \& Flores, A. E. 2004. Patrón de distribución espacial y fluctuación poblacional de Eutetranychus banksi (McGregor) y su depredador Euseius mesembrinus (Dean) (Acari: Tetranychidae, Phytoseiidae) en una huerta de naranjos. Acta Zoológica Mexicana, 20: 147-155.

Lomelí-Flores, J. R., Rodríguez-Leyva, E., Otero-Colina, G., Mora-Aguilera, G. \& EsquivelChávez, F. 2008. Primer reporte de Tetranychus merganser (Acari: Tetranychidae) sobre Opuntia ficus-indica L. en Tlalnepantla, Morelos. Entomología Mexicana, 7: 21-25.

McGregor, E. A. 1914. Four new tetranychids. Annals of the Entomolical Society of America, 7: 354364.

McMurtry, J. A. 1985. Citrus, pp. 339-347. In: W. Helle and M. W. Sabelis (Eds.) Spider mites, their biology, natural enemies and control. Vol-1B. Elsevier, Wageningen, Netherland.

McMurtry, J. A. \& Croft, B. A. 1997. Life-styles of phytoseiid mites and their roles in biological control. Annual Review of Entomology, 42: 291-321.

Mesa, N. C., Ochoa, R., Welbourn, W. C., Evans, G. A. \& de Moraes, G. J. 2009. A catalog of the Tenuipalpidae (Acari) of the world with a key to genera. Zootaxa, 2098: 1-185.

Moraes, G. J., McMurtry, J. A., Denmark, H. A. \& Campos, C. B. 2004. A revised catalog of the mite family Phytoseiidae. Zootaxa, 434: 1-494.

Muma, M. H. 1970. Natural control potential of Galendromus floridanus (Acarina: Phytoseiidae) on Tetranychidae on Florida citrus trees. Florida Entomologist, 53: 79-88.

Ochoa, R., Aguilar, H. \& Vargas, C. 1991. Ácaros fitófagos de América Central: Guía ilustrada. CATIE, Turrialba, Costa Rica, 252 pp.

Oldfield, G. N. 1996. Diversity and host plant specificity, pp.199-216. In: E. E. Lindquist, M. W. Sabelis and J. Bruin. (Eds.). Eriophyid mites, their biology, natural enemies and control. Elsevier, Wageningen, Netherland.

Otero-Colina, G. 1986. Ácaros colectados en el estado de Tabasco, México y su importancia. Folia Entomológica Mexicana, 69: 127-147.

Pantoja, A., Follett, P. A. \& Villanueva-Jiménez, J. A. 2002. Pests of papaya, pp. 131-156. In: J. E. Peña, J. L. Sharp and M. Wysoki. (Eds.). Tropical fruit pest and pollinators. Biology, economic importance, natural enemies and control. CABI Publishing, Wallingford.

Pritchard, A. E. \& Baker, E. W. 1955. A Revision of the spider mite family Tetranychidae. Pacific 
Coast Entomological Society Memories. Series 2, 472 p.

Reséndiz, G. B. \& Fausto-Moya, T. J. 2010. Identificación de los ácaros asociados al papayo (Carica papaya L.). pp. 25-31. In: M. C. Sánchez G., J. S. Sandoval I. and E. G. Estrada V. (Eds). Memorias del Primer Simposio Internacional de Acarología. Universidad Autónoma Chapingo, México.

Rodríguez-Navarro, S. 1999. Ácaros, 136-138 pp. In: A. C. Deloya-López and J. E. ValenzuelaGonzález (Eds.). Catálogo de insectos y ácaros de los cultivos agrícolas de México. Sociedad Mexicana de Entomología, México.

Rodríguez-Navarro, S. \& Estébanes-González, M. L. 1998. Acarofauna asociada a vegetales de importancia agrícola y económica en México. Universidad Autónoma Metropolitana-Xochimilco, México, 103 pp.

Salas, L. A. 1978. Algunas notas sobre las arañitas rojas (Tetranychidae: Acari) halladas en Costa Rica. Agronomía Costarricense, 2: 47-59.

Smith-Meyer, M. K. P. 1996. Ornamental flowering plants, pp. 641-650. In: E. E. Lindquist, M. W. Sabelis and J. Bruin (Eds.). Eriophyid mites, their biology, natural enemies and control. Elsevier, Wageningen, Netherland.

Takano-Lee, M. \& Hoddle, M. 2002. Predatory behaviors of Neoseiulus californicus and Galendromus helveolus (Acari: Phytoseiidae) attacking Oligonychus perseae (Acari: Tetranychidae). Experimental and Applied Acarology, 26: 13-26.

Tanigoshi, L. K. \& McMurtry, J. A. 1977. The dynamics of predation of Stethorus picipes (Coleoptera. Coccinellidae) and Typholodromus floridanus on the prey Oligonychus punicae (Acarina: Phytoseiidae, Tetranychidae). Hilgardia, 45: 237-288.

Téliz-Ortiz, D., Mora-Aguilera, A., Nieto-Angel, D., Gonsalves, D., García-Pérez, E., Matheis, L. \& Ávila-Resendiz, C. 1991. Mancha anular del papayo en México. Revista Mexicana de Fitopatología, 9: 64-68.

Tuttle, D. M., Baker, E. W. \& Abbatiello, M. J. 1976. Spider mites of Mexico (Acari: Tetranychidae). International Journal of Acarology, 2: 1-102.

Ullah, M. S., Moriya, D., Badii, M. H., Nachman, G. \& Gotoh, T. 2011. A comparative study of development and demographic parameters of Tetranychus merganser and Tetranychus kanzawai (Acari: Tetranychidae) at different temperatures. Experimental and Applied Acarology, 54: 1-19.

Valencia-Domínguez, H. M., Otero-Colina, G., Santillán-Galicia, M. T. \& Hernández-Castro, E. 2011. Acarofauna en papaya var. Maradol (Carica papaya L.) en el estado de Yucatán, México. Entomotropica, 26: 27-40.

Walter, D. E. \& Krantz, G. W. 2009. Collection, rearing and preparing specimens. pp. 83-96. In: G. W. Krantz and D. E. Walter. A manual of Acarology. Third Edition. Tech University Press, Lubbock, Texas, U. S. A.

Wang, D. S. \& Ma, E. P. 1993. New species and records of tetranychid mites from Eastern China. Acta Entomologica Sinica, 36: 379-381.

Zhang, Z. Q. \& Jacobson, R. J. 2000. Using adult female morphological characters for differentiating Tetranychus urticae complex (Acari: Tetranychidae) from greenhouse tomato crops in UK. Systematic and Applied Acarology, 5: 69-76. 